\title{
Production Technology for the Preparation of Wild Apricot Fruit Sweet Vermouth
}

\author{
Ghan Shyam A* and Joshi VK \\ Department of Food Science and Technology, India
}

ISSN: 2640-9208

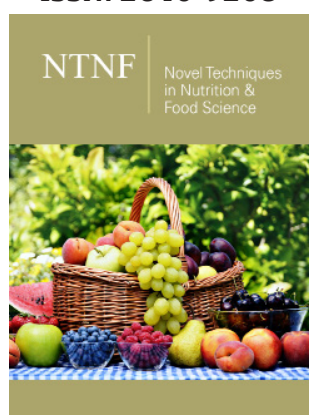

${ }^{* 1}$ Corresponding author: Ghan Shyam Abrol, Department of Food Science and Technology, India

Submission: 酸January 25, 2019

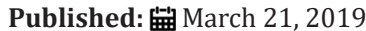

Volume 3 - Issue 4

How to cite this article: Ghan $\mathrm{S} \mathrm{A}$ Joshi V. Production Technology for the Preparation of Wild Apricot Fruit Sweet Vermouth. Nov Tech Nutri Food Sci. 3(4). NTNF.000569.2019.

DOI: 10.31031/NTNF.2019.03.000569

Copyright@ Ghan Shyam Abrol, This article is distributed under the terms of the Creative Commons Attribution 4.0 International License, which permits unrestricted use and redistribution provided that the original author and source are credited.

\begin{abstract}
Introduction: Wild apricot fruit (Prunus armenica L.) grows naturally in hilly areas of northern India. The fruit is highly acidic, fibrous but low in TSS $\left({ }^{\circ} \mathrm{B}\right)$ and thus, not utilized commercially.

Materials and methods: Wild apricot vermouth was prepared having different alcohol levels $(15,17$ and $19 \%)$, different sugar levels (8,10 and $\left.12{ }^{\circ} \mathrm{B}\right)$ and spices and herbal extract levels (2.5 and 5.0\%).

Results and discussion: Out of three different alcohol levels used, the highest TSS, ethanol, higher alcohols and total esters were found in 19\% alcohol level vermouth whereas, total sugars, titratable acidity and total phenols were recorded in $15 \%$ alcohol level wild apricot vermouth. Out of three different sugar level used, vermouth having $12 \%$ sugar had the highest TSS, reducing sugars, total sugars and total esters as well as total carotenoids. Further, 5\% spices extract had more pronounced effect on TSS, total sugars, titratable acidity, total esters and total phenols than $2.5 \%$ spices level.
\end{abstract}

Conclusion: The base wine contained residual sugars, desirable acidity, proper amount of TSS, low volatile acidity and satisfactory amount of tannins and total esters and hence was found suitable for vermouth preparation. Based on physic-chemical quality characteristics, a product having $8 \%$ sugar, $17 \%$ alcohol and $5 \%$ spices extract was adjudged to be best by the judges.

Keywords: Wild apricot fruit; Base wine; Spices and herbal extract; Vermouth

\section{Introduction}

Wild apricot fruit (Prunus armenica L.) is a drupe and is found growing naturally in hilly areas of northern India [1]. These include the major parts of Jammu \& Kashmir; Kinnaur, Kullu, Chamba, Lahul- Spiti districts of Himachal Pradesh and the hilly areas of Uttar Pradesh $[2,3]$. The fruits are rarely eaten fresh. The fruit contains about 81 percent pulp and is also a good source of nutrients viz., vitamins, sugar, acid, TSS, vitamin C, protein and minerals mainly phosphorous, potassium, calcium, magnesium and iron. But the fruit is not as popular as fresh cultivated fruit. Being more acidic (acidity 1.6-3.4\% as MA) and fibrous thus, has no market value $[2,4]$. The tribal people of the area utilize the major portion of the crop to prepare distilled beverage using crude technology, which completely lacks in nutrients and even have considerably higher methanol content. These defects are due to lack of scientific technology adopted by them in preparation of such beverages. To prepare wild apricot wine, a process has been standardized where in a dilution of 1:2 (pulp: water) was optimized to prepare wine of acceptable physic-chemical and sensory quality [5,6]. A wine containing spices and herb is called vermouth. Preparation technique of vermouth has been optimized from other fruits also, like sand pear, plum and apples [7]. But there is no information on the suitability of this fruit for the preparation of vermouth nor there is any documentation of a method to prepare such a wine. Therefore, a study was made to standardize the technique to prepare vermouth from wild apricot fruit.

\section{Materials and methods}

The fruits of wild apricot were procured from Kinnaur Distt. of Himachal Pradesh and were converted into pulp. The pulp was stored with 2000ppm KMS and was employed for fermentation after removal of KMS by heating. Cane sugar and di-Ammonium hydrogen phosphate (DHAP) used to ameliorate the must for preparation of base wine was procured from local market. Pectinase enzyme used was manufactured by M/S Triton Chemicals, 
Mysore, India, under the brand name of 'Pectineal'. Different spices and herbs for the preparation of vermouth were obtained from the department of forest products, college of forestry, Nauni, Solan (India). Base wine prepared by diluting the pulp in 1:2 ratio with water, $200 \mathrm{ppm} \mathrm{SO}_{2}$, DAHP $0.1 \%$ and $0.5 \%$ pectinase enzyme was added. A $24 \mathrm{hrs}$ old activated yeast culture (Saccharomyces cerevisiae var. ellipsoideus strain UCD 595) was prepared and used for fermentation. A part of the base wine was distilled into brandy as per the standard procedure [8]. List of spices and herbs used to prepare extract for use in wild apricot vermouth production are Piper nigrum L. (0.75g/L), Coriander sativum L. (0.70g/L), Cuminum cyaninum L. $(0.50 \mathrm{~g} / \mathrm{L})$, Syzygium aromaticum L. $(0.25 \mathrm{~g} / \mathrm{L})$, Amomum subulatum Roxb. (0.50g/L), Crocus sativus L. (0.01g/L), Myristica fragrans $(0.25 \mathrm{~g} / \mathrm{L})$, Cinnamomum zeylanicum Beryn $(0.25 \mathrm{~g} / \mathrm{L})$, Papaver somniferum L. $(1.00 \mathrm{~g} / \mathrm{L})$, Zingiber officinale Rosc $(1.00 \mathrm{~g} / \mathrm{L})$, Woodfordia floribunda $(0.25 \mathrm{~g} / \mathrm{L})$, Asparagus $s p$. $(0.10 \mathrm{~g} / \mathrm{L})$, Withania somnifera $(0.20 \mathrm{~g} / \mathrm{L})$, Justicia adhatoda $\mathrm{sp}$. $(0.25 \mathrm{~g} / \mathrm{L})$ and Rosmarinus officinalis $(0.10 \mathrm{~g} / \mathrm{L})$ [9]. To optimize and develop wild apricot vermouth, different ethanol concentrations $(15,17$ and 19$)$, sugar concentrations $(8,10$ and $12 \%)$ and spices extract ( 2.5 and $5.0 \%$ ) were employed and the products were evaluated.

Titratable acidity was estimated by titrating a known aliquot of the sample against N/10 NaOH solution using phenolphthalein as an indicator. The titratable acidity was calculated and expressed as per cent malic acid [10]. Total soluble solids (TSS) were measured using an Erma hand refractometer ( 0 to $32{ }^{\circ} \mathrm{B}$ ) and the results were expressed as degree brix $\left({ }^{\circ} \mathrm{B}\right)$. The readings were corrected by incorporating the appropriate correction factor for temperature variation [11]. The total phenols content in different wines were determined by Folin Ciocalteu procedure given by Singleton \& Rossi [12]. The total and reducing sugars of fruit and vermouth were estimated by Lane and Eynon volumetric method [11] by titrating the sample against Fehling's solutions. Ascorbic acid content was determined as per AOAC [11] method using 2,6-dichlorophenolindophenol dye. Volatile acidity of wild apricot vermouth was determined by the standard method [8]. Quantity of ethanol in wine/vermouth was estimated by spectrophotometric method [13] while that in brandy was determined by alcoholometer [8]. Total esters were estimated as per the method of Liberaty [14]. Statistical analysis of the quantitative data of chemical parameters obtained from the experiments was done by completely randomized design (CRD) factorial as per standard method [15].

\section{Results and Discussion}

\section{Physico-chemical Characteristics of fruit and base wine}

The physico-chemical characteristics of wild apricot fruit are given Table 1. It is clear that the fruit was of medium size but has quite good amount of pulp. The kernel has sweet taste and the fruit contained $10.0{ }^{\circ} \mathrm{B}$ total soluble solids, while titratable acidity (as malic acid) was very high. The reducing sugars and total sugars were, however, low. Carotene content was recorded to be $2.50 \pm 0.07 \mathrm{mg} / 100 \mathrm{~g}$. The TSS of wild apricot base wine was recorded as $8.2 \circ \mathrm{B}$, whereas acidity and $\mathrm{pH}$ were recorded $0.764 \%$ and 3.152 respectively. The low value of TSS revealed that the proper fermentation has taken place. The low volatile acidity of $(0.025 \%$ A.A.), shows the soundness of wine, which was within the limits of the legal standards $(0.040 \%)$ recommended [8]. It also reflects that no bacterial spoilage in the base wine has taken place. Total esters, total phenols and sugar content were found within the limits. Based on the physico-chemical characteristics it is concluded that the base wine was sound and was of medium alcohol content, thus suitable for conversion into vermouth.

Table 1: Physico-chemical characteristics of fresh wild apricot fruit.

\begin{tabular}{|c|c|}
\hline Physico-Chemical Characteristics & Mean $\pm \mathrm{SD}^{*}(\mathrm{n}=10)$ \\
\hline Fruit weight $(\mathrm{g})$ & $12.42 \pm 3.32$ \\
\hline Fruit diameter $(\mathrm{cm})$ & $2.46 \pm 0.38$ \\
\hline Fruit volume $\left(\mathrm{cm}^{3}\right)$ & $10.55 \pm 1.35$ \\
\hline TSS $\left({ }^{\circ} \mathrm{B}\right)$ & $10.00 \pm 0.24$ \\
\hline Titratable acidity (\% MA) & $2.23 \pm 0.16$ \\
\hline Ascorbic acid (mg/100g) & $37.30 \pm 0.13$ \\
\hline Reducing sugars (\%) & $4.83 \pm 0.22$ \\
\hline Total sugars (\%) & $6.16 \pm 0.03$ \\
\hline Carotenoids (mg/100g) & $2.50 \pm 0.07$ \\
\hline Pulp content (\%) & $77.00 \pm 0.2$ \\
\hline
\end{tabular}

*SD: Standard Deviation

\section{Fermentability of 'must'}

The fermentation behavior of wild apricot must (TSS 24 oB) measured as fall in TSS with time is depicted in Figure 1. As expected, fermentation during initial period was quite high but declined near the end of fermentation. During fermentation, sugar was utilized by the yeast to form ethanol and thus reduced TSS content. Rate of fermentation (RF, ${ }^{\circ} \mathrm{B} / 24 \mathrm{hr}$ ) of wild apricot must was recorded to be 1.22. It indicates satisfactory fermentation rates and indirectly reflects that the pre-requisite for proper alcoholic fermentation such as yeast culture and proper amount of nitrogen in the must might have been met $[8,16,17]$.

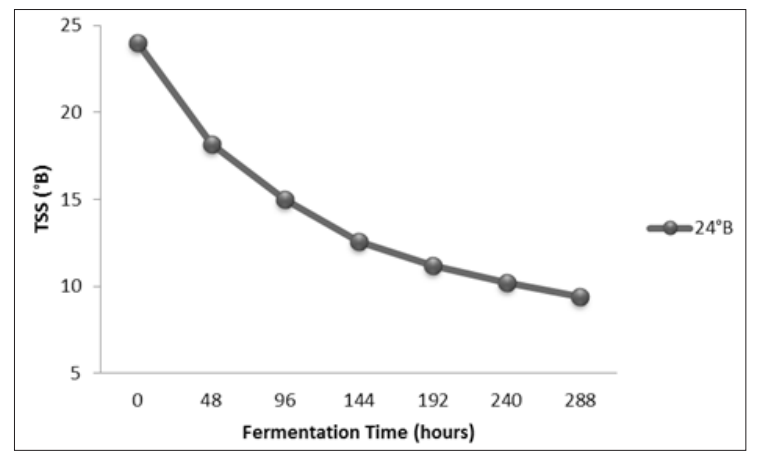

Figure 1: Changes in TSS during fermentation of wild apricot fruit must.

\section{Effect of treatments}

Effect of ethanol level: (Figure 2-5) shows the effect of alcohol levels on physic-chemical characteristics of vermouth. With an increase in alcohol level, TSS of vermouth was increased and ranged 
between 17.09 to $17.45 \%$. However, a significant decrease in reducing sugars content (5.55 to $5.38 \%$ ) of wild apricot vermouth took place with increase in alcohol level. Increase in reducing sugars took place in all the treatments because of hydrolysis of non-reducing sugars into reducing sugars. The decrease in reducing sugars with increase in alcohol content may be because of dilution effect. Similarly, total sugars decreased from 10.41 to $9.96 \%$. Titratable acidity of $17 \%$ alcohol level vermouth was found at par with $19 \%$ alcohol level vermouth. The lowest (0.026\% A.A.) volatile acidity was found in $15 \%$ alcohol level vermouth and highest $(0.029 \%$ A.A.) in $19 \%$ vermouth which was at par with $17 \%$ alcohol level vermouth (0.028\% A.A.). It is the contribution of addition of brandy. An increase in total esters took place with the increase in alcohol level and was found in the range of 260.8 to $267.4 \mathrm{mg} / \mathrm{L}$. It is expected as brandy addition contains esters that might be contributed in wine. Amerine et al. [8] have summarized total esters in various wines ranging between 200 and $400 \mathrm{mg} / \mathrm{L}$. With the increase in alcohol levels, the quantity of total phenols was reduced (range between 454.4 to $446.4 \mathrm{mg} / \mathrm{l}$ ). Comparable results have been reported in sand pear vermouth, plum vermouth and apple vermouth [18-20]. The highest $(1.122 \mathrm{mg} / \mathrm{L})$ total carotene was recorded in 15\% alcohol level wild apricot vermouth and lowest $(1.118 \mathrm{mg} / \mathrm{L})$ in $19 \%$ alcohol level vermouth. It is apparent that addition of brandy in the vermouth decrease the color hence carotene also.

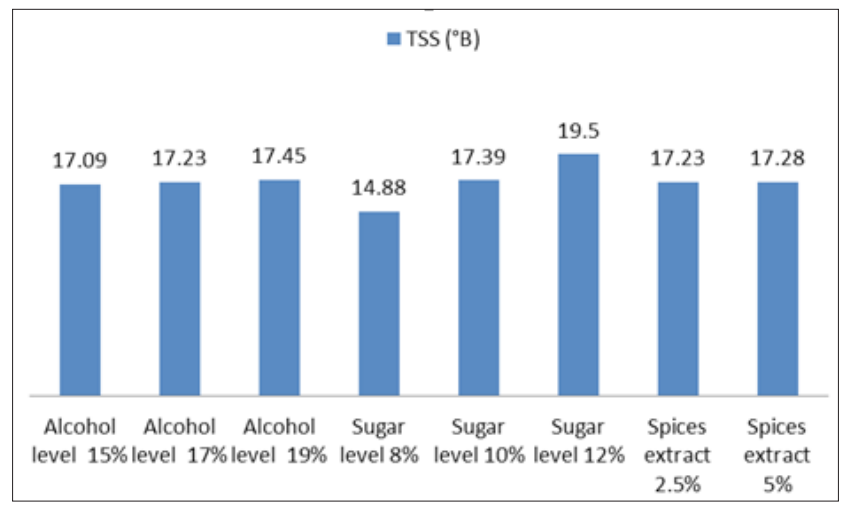

Figure 2: Effect of different treatments on TSS content of wild apricot sweet vermouth.

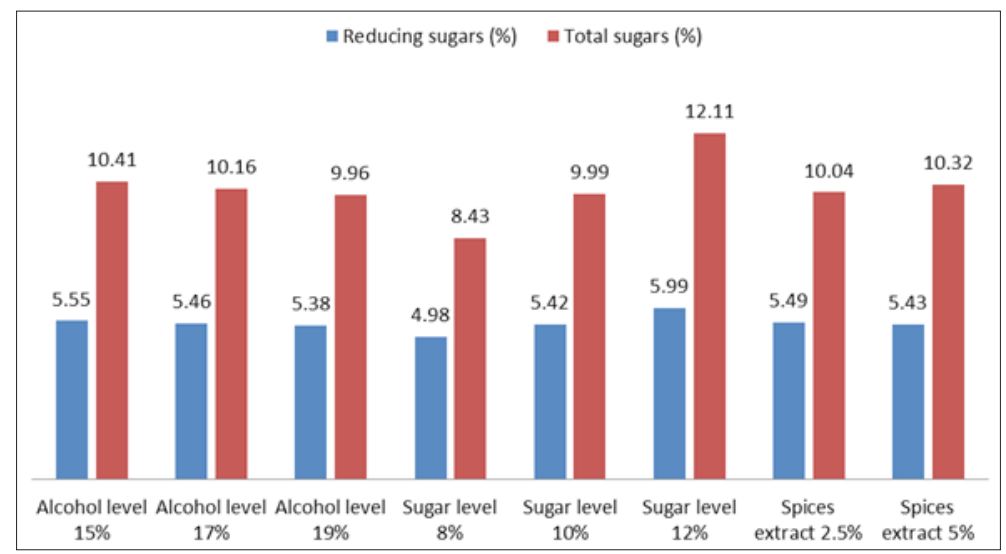

Figure 3: Effect of different treatments on reducing and total sugars content of wild apricot sweet vermouth.

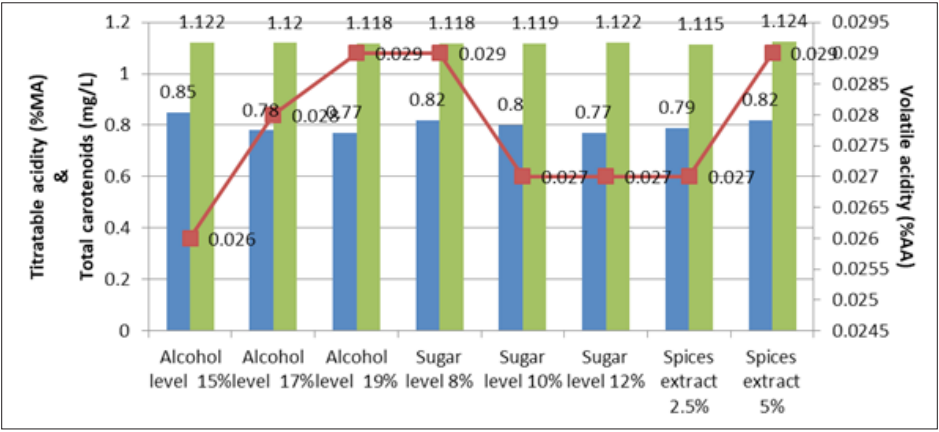

Figure 4: Effect of different treatments on titratable acidity, total carotenoids and volatile acidity content of wild apricot sweet vermouth. 


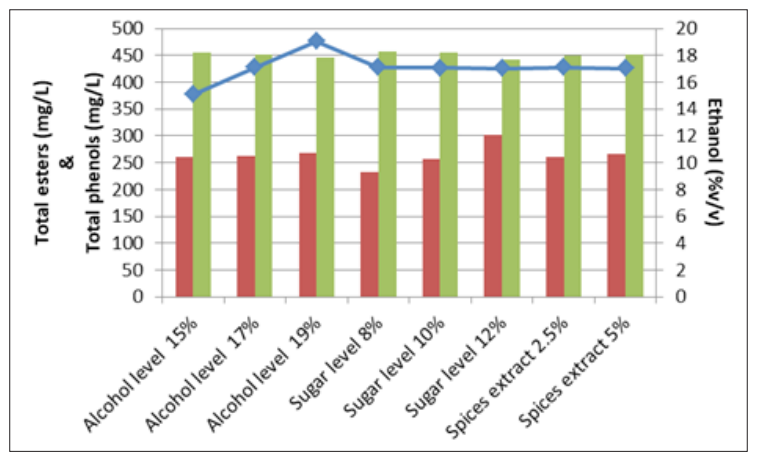

Figure 5: Effect of different treatments on total esters, total phenols and ethanol content of wild apricot sweet vermouth.

Effect of sugar level: A significant increase in TSS level took place with the increase in sugar level from 14.88 to $19.50{ }^{\circ} \mathrm{B}$ (Figure 2-5). Same was the case of reducing and total sugars content. With the increase in sugar level, titratable acidity decreased (range between 0.82 to $0.77 \%$ ). Out of three different sugar concentrations used for vermouth production (8,10 and 12\%), concentration of $12 \%$ sugar level wild apricot vermouth was found at par with $10 \%$ sugar level wild apricot vermouth, whereas, $8 \%$ sugar level vermouth was found to be significantly different from these. However, for volatile acidity, out of vermouth with three sugar levels $(8,10$ and $12 \%)$ that with $10 \%$ sugar level was at par with $12 \%$ sugar level vermouth. The highest $(301.3 \mathrm{mg} / \mathrm{L})$ total esters were found in $12 \%$ sugar level vermouth and lowest in $8 \%$ sugar level vermouth $(233.1 \mathrm{mg} / \mathrm{L})$. With increase in sugar level, decreases in total phenols concentration was recorded. Since sugar is not expected to contain volatile acids, esters or phenols, therefore with increase in sugar levels, decrease in these parameters took place.

Effect of spices level: Vermouth having 5\% spices level had higher level of TSS (17.28 $\left.{ }^{\circ} \mathrm{B}\right)$ than that with $2.5 \%$ spices level (Figure 2-5). It is the contribution of soluble solids by spices extract. Vermouth of $5 \%$ spiced level had lower reducing sugars than that with $2.5 \%$ level apparently due to dilution effect of higher concentration of spices extract, as observed in apple vermouth [19]. Out of two spices level used, product with 5\% spices extract level had higher $(10.32 \%)$ quantity of total sugars than that with $2.5 \%$ spices level $(10.04 \%)$. Vermouth with $5 \%$ spices extract had lower titratable acidity $(0.79 \%)$ than $2.5 \%$ spices level. Out of two different concentrations of spices extract used for wild apricot vermouth production, $2.5 \%$ spices level vermouth had higher (17.11\%) ethanol quantity than that with $5 \%$ spices extract vermouth $(17.04 \%)$. It is due to the dilution by higher quantity of spices extract. Increased concentration of spices extract (5\%) recorded higher $(0.029 \%$ A.A.) volatile acidity than $2.5 \%$ spices level vermouth $(0.027 \%$ A.A.). Higher quantity of spices extracts imparted higher total esters $(266.8 \mathrm{mg} / \mathrm{L})$ than the lower level $(260.5 \mathrm{mg} / \mathrm{L})$. The spices extract had total soluble solids that may contain acids, sugars and salts, naturally its addition increased to acidity, reduced $\mathrm{pH}$ and increased total and reducing sugars (Table 2). Addition of higher quantity spices extract level (5\%) gave higher quantity of total phenols $(452.1 \mathrm{mg} / \mathrm{L})$. With the increase in spices extract level a significant increase in total carotenoids content also took place. It is expected as the color of extract might have added the pigment to the vermouth. Higher quantity of total phenols was recorded in vermouth with $5 \%$ extract than that with $2.5 \%$ extract. The spices extract in general increased total esters, volatile acids and total phenols. These are the contributions made by the extract to the vermouth. In earlier work, similar observations were also obtained [20].

Table 2: Physico-chemical characteristics of base wine.

\begin{tabular}{|c|c|}
\hline Physico-Chemical Characteristics & Mean \pm SD $^{*}$ \\
\hline TSS $\left({ }^{\circ} \mathrm{B}\right)$ & $8.20 \pm 0.07$ \\
\hline Titratable acidity (\%MA) & $0.76 \pm 0.02$ \\
\hline Alcohol (\%v/v) & $10.64 \pm 0.09$ \\
\hline Reducing sugars (\%) & $0.34 \pm 0.01$ \\
\hline Total sugars (\%) & $1.11 \pm 0.02$ \\
\hline Volatile acidity (\%AA) & $0.025 \pm 0.002$ \\
\hline Total phenols (mg/L) & $253.60 \pm 0.8$ \\
\hline Total esters (mg/L) & $135.40 \pm 0.55$ \\
\hline
\end{tabular}

*SD: Standard Deviation; $\mathrm{n}=3$

\section{Conclusion}

The fruit is acidic in nature and contains less TSS, but the vermouth prepared from it was quite acceptable product. It was apparent that variations in the alcohol, sugar level and spices extract concentration effected the physico-chemical qualities of wild apricot vermouth. Out of three different sugar levels used in vermouth preparation, for overall acceptability, vermouth of $8 \%$ sugar was preferred. Out of the three alcohol levels tried, $17 \%$ alcohol was preferred based on sensory evaluation. Maturation of vermouth led to a significant improvement in quality. It is concluded that, vermouth with $5 \%$ spices level, $8 \%$ sugar and $17 \%$ alcohol level was the best.

\section{References}

1. Parmar C, Sharma AK (1992) Chulli: A wild apricot from Himalayan Cold Desert Region. Fruit Varieties Journal 46(1): 35-36.

2. Sharma SD (1994) Variation in local apricots growing in kinnaur of himachal pradesh (India). Varieties Journal 48: 225-228.

3. Sharma JK (2000) Morphological studies on apricot and its wild relatives. Journal Hill Research 13: 5-10. 
4. Parmar C, Kaushal MK (1982) Prunus armenica. In: Wild Fruits, Kalyani Publishers, New Delhi, pp. 66-69.

5. Joshi VK, Bhutani VP, Lal BB, Sharma R (1990) A method for the preparation of wine from the wild apricot, Indian Food Packer 44: 50-55.

6. Joshi VK, Bhutani VP, Sharma RC (1990) Effect of dilution and addition of nitrogen source on chemical, mineral and sensory qualities of wild apricot wine. American Journal of Enology and Viticulture 41(3): 229231.

7. Panesar PS, Kumar N, Marwaha SS, Joshi VK (2009) Vermouth production technology-an overview. NPR 8(4): 334-344.

8. Amerine MA, Berg HW, Kunkee RE, Qugh CS, Singleton VL, et al. (1980) The technology of wine making. In: $4^{\text {th }}$ edn. AVI Publishing Com, Inc. Westport, CT.

9. Joshi VK (1997) Fruit wines. $2^{\text {nd }}$ edn, Directorate of Extension Education, YS Parmar UHF, Noninsulin, India.

10. Ranganna S (1986) Handbook of analysis and quality control for fruit and vegetable products. Tata McGraw Hill Publishing Company Ltd, New Delhi, p.1112.

11. AOAC (1980) Association of official analytical chemists. In: Hortwitz W (ED.), $13^{\text {th }}$ edn. Official Methods of Analysis, Washington, USA, p.1015.

12. Singleton VL, Rossi JA (1995) Colorimetry of total phenolics with phosphomolybdic phosphotungstic acid reagents. American Journal of Enology and Viticulture 16: 144-158.
13. Caputi A, Ueda M, Brown T (1968) Spectrophotometric determination of ethanol in wine. American Journal of Enology and Viticulture 19: 160165.

14. Liberaty V (1961) Ester determination and their applications to wine. M.Sc. Thesis, California, USA.

15. Cockrane WG, Cox GM (1963) Experimental Designs. In: $14^{\text {th }}$ edn, Asia Publishing House, Bombay, India.

16. Azad KC, Vyas KK, Joshi VK, Sharma RR (1987) Observations on juice and cider made from scabbed apple fruit. Indian Food Packer 41: 47-54.

17. Zoecklein BW, Fugelsang KC, Gump BH, Nury FS (1995) Wine analysis and production. Chapman Hall, New York.

18. Attri BL, Lal BB, Joshi VK (1994) Preparation and evaluation of sand pear vermouth. Journal of Food Science and Technology 30: 435-437.

19. Joshi VK, Sandhu DK (2000) Influence of ethanol concentration, addition of spices extract, and level of sweetness on physic-chemical characteristics and sensory quality of apple vermouth. Brazilian Archives of Biology and Technology 43(5): 537-545.

20. Joshi VK, Attri BL, Mahajan BVC (1991) Production and evaluation of vermouth from plum fruits. Journal of Food Science and Technology 28: 138-141. 